\title{
The Effect of Village Government Worker Readiness on Communication, Information and Education (IEC) About Village Funds and Community Empowerment in Klungkung Regency
}

\author{
Ni Kadek Riana Mustika Dewi *, I Wayan Wenagama **, I Ketut Sudibia **, A.A.I.N Marhaeni ** \\ * Faculty of Economics and Business, Udayana University, Bali, Indonesia \\ ** Faculty of Economics and Business, Udayana University, Bali, Indonesia \\ *email correspondent: mustikadewica8@gmail.com \\ DOI: 10.29322/IJSRP.11.01.2021.p10963 \\ http://dx.doi.org/10.29322/IJSRP.11.01.2021.p10963
}

\begin{abstract}
This study aims to determine how the effect of Village Government Worker readiness on IEC village funds and community empowerment in Klungkung Regency. The study population are all government workers and people who live in Klungkung Daratan, with a sample size of 259 respondents who are determined based on the sample quota. The sampling technique used is a non-random sampling technique. Data collected through a questionnaire and analyzed using path analysis
\end{abstract}

Keywords: community empowerment, Village Government Worker Readiness, village fund IEC

\section{INTRODUCTIO}

Indonesia applies a democratic government system. Based on Antlov, et al. (2014), The implementation of democracy in government is the principle of decentralization and regional autonomy. Regional autonomy is the right, authority and obligation of the autonomous region to self-regulate the affairs of government and local communities. Apart from regional autonomy, village autonomy is also implemented. Sulumin (2015) defines village autonomy as the authority for the village in regulating the interests of the community in accordance with existing initiatives. The goal of village autonomy is to revitalize village development, make community institutions more representative and accountable, and improve government-community relations. The issuance of Law No. 6 of 2014 concerning Villages, the presence of a law on villages is a strengthening of the village's status as community government, as well as a basis for advancing society and empowering village communities

Although villages are given autonomy in managing their own households, the implementation of this autonomy will not be successful without a source of income. Several things cause villages to need sources of income, namely: (a) The village has small funds where the source of income is very dependent on small grants, (b) Village Original Income is also still low due to the capacity of the village's human resources (HR) which are still low in managing natural resources so that the welfare of communities is also low, (c) Operational funds for public services are also low. (d) The programs implemented in the village are top-down so that they are not in accordance with the priority needs of the village community. According to George (2004), programs with a top-down mechanism have a weakness, they are run without community participation. In connection with these problems, the government provides support in the form of financial balancing funds between the central government and regional governments, where a minimum of $10 \%$ of the balance funds received by districts / cities minus the Special Allocation Fund is allocated for villages. This became known as the Village Fund Allocation

The Indonesian village fund program is the first and largest development assistance program in the world. The main purpose of the existence of village funds is to increase the productivity of villages in Indonesia to be more independent, and to increase equitable development. One indicator of the success of development carried out by the village government is the Building Village Index. Based on research conducted by Marhaeni, et al (2019), it shows that in general Bali Province in 2017 was still in a developing status, while in 2019 on average, Bali Province had reached advanced status. the role of village funds is very influential in increasing the development index, because before and after the existence of village funds there is an increase in the development index at the village level. This is reflected in one district, namely Klungkung Regency. In 2016, Klungkung District had 2 underdeveloped villages, in 2017 there were no more underdeveloped villages due to an increase in the index so that disadvantaged villages could change their status to developing villages, and in 2019 they gained advanced status.

Klungkung Regency is one of the districts that is geographically unique and with an administrative area that is not too large and has the lowest population in Klungkung Regency reaching 179,100 people. Even though it has a small population, Klungkung Regency occupies the highest position seen from the Gini Ratio (inequality of income and wealth distribution) which reaches 0.39 which indicates that there is an increasingly unequal or there is a gap in income and wealth in the area, in this case Klungkung Regency. Efforts to address disparities between regions or the high rate of inequality in Klungkung Regency is by applying the "building from the periphery" paradigm through the Village Fund Program to develop disadvantaged areas and rural areas. 
Klungkung Regency, which is a district with a small administrative area, received a total allocation of IDR $51,533,962,000$. The question that arises is about the readiness of Village Government Worker in managing these funds in order to achieve the expected goals. Gayatri, et al (2017) stated that the demands for financial management accountability are getting higher but many government organizations are unable to realize accountability for government financial management properly. The management of village funds is expected to be carried out well by Village Government Worker to achieve the goals of village funds, one of which is strengthening village communities as the subject of development or empowering the community.

Efforts to empower the community are an action that cannot be separated from improving education. Gonçalves Barbosa et al. (2016) assume that people are better able to improve their ability to act, think critically and realistically, and support economic development and social rights through their education. Education regarding village funds can be provided to the community by involving the important role of Village Government Worker in establishing communication, providing information and educating the community about the existence of the village fund program. Based on this, researchers wanted to know the effect of Village Government Worker readiness on communication, information and education (IEC) about village funds and community empowerment in Klungkung Regency.

According to Marhaeni, et al. (2019) IEC village funds is a prerequisite for the success of the village fund program. Nielsen and Christian (2003) also explain that empowerment is related to the dissemination of information, providing knowledge, and appreciation of performance in encouraging increased skills. Research conducted by Hairi Firmansyah (2012) shows that the role of the facilitator, in this case the village government, greatly determines the success of the empowerment program, namely the realization of community empowerment. In connection with the influence of Village Government Worker readiness on community empowerment, so that the empowerment program can run effectively, it is necessary to restructure community institutions to realize freedom of expression, besides communication support makes it easier for the community to obtain the information needed in empowerment activities. Syafruddin, et al (2019) show that communication support has a very real effect on the dynamics of community empowerment as a result of the empowerment program. This community empowerment program can be successful if it is supported by two-way communication between aid providers and beneficiaries. No matter how good the program offered, if the communication process is not smooth, it can result in a smooth process of empowerment activities carried out. Research conducted by Dahyar Daraba (2015) shows that communication has a positive effect on the success rate of the empowerment program. Based on the description above, the hypothesis that can be put forward is:

H1: The readiness of Village Government Worker has a positive effect on IEC village funds in Klungkung Regency.

H2: Village Government Worker readiness has a positive effect on community empowerment in Klungkung Regency

H3: Village fund IEC has a positive effect on community empowerment in Klungkung Regency.

H4: IEC village funds mediate the effect of Village Government Worker readiness on community empowerment in Klungkung Regency.

\section{METHODS}

This research is conducted in Klungkung Regency which is the district with the highest Gini Ratio (inequality of income and wealth distribution) in Bali Province in 2018. The location selection is also based on the population in Klungkung Regency which is the lowest in Bali Province so it is relevant as a location for related research. community development. Furthermore, with the assumption that the general characteristics of the villages in Klungkung Daratan are the same, and considering time, cost and labor, this research is focused on Klungkung District, Banjarangkan District and Dawan District.

The population in this study are Village Government Worker and village communities in Klungkung Regency. The sampling method used is nonrandom sampling. The number of samples used in this study are determined based on the quota sampling, and took a sample of 4 village people and 3 Village Government Worker as respondents with a total of 259 respondents. The data are collected using a questionnaire and measured based on an ordinal scale. This study uses qualitative data which will later be quantified by the measurement scale of each variable so that it can be processed using regression analysis with the help of SPSS. This study used path analysis, namely the analysis used to determine the effect of Village Government Worker readiness on IEC village funds and community empowerment in Klungkung Regency. The following is the form of the equation used in research.

$\mathrm{Y}_{1}=\beta_{1} \mathrm{X}_{1}+\mathrm{e}_{1} \ldots$

$\mathrm{Y}_{2}=\beta_{2} \mathrm{X}_{1}+\beta_{3} \mathrm{Y}_{1}+\mathrm{e}_{2}$

\section{RESULTS AND DISCUSSION}

\section{A. Path Analysis}

The path coefficient in this study is obtained from the regression results with the simple regression method using the SPSS 24 program on the equation model. This section will be resolved in stages through the regression equation model as follows.

1) Model 1: Effect of Village Government Worker Readiness (X1) on Village Fund IEC (Y1).

2) Model 2: Effect of Village Government Worker Readiness (X1) and Village Fund IEC (Y1) on Community Empowerment (Y2)

Table 1. Regression Test Results of Village Government Worker Readiness Against IEC Village Funds Model Unstandardized Coefficients Standardized Coefficients Sig. 


\begin{tabular}{|c|c|c|c|c|c|c|}
\hline & & B & Std. Error & Beta & & \\
\hline & (Constant) & 9,907 & 1,060 & & 9,346 & ,000 \\
\hline 1 & $\begin{array}{l}\text { Village Government } \\
\text { Worker Readiness }\end{array}$ & ,368 & ,034 & ,559 & 10,794 & ,000 \\
\hline
\end{tabular}

Primary Data, 2020

Based on Table 1, $\alpha=0,05, \operatorname{sig} \mathrm{t}_{1}=0,000$ and beta value 0,559 . This means that the research hypothesis $\mathrm{H} 0$ is rejected and $\mathrm{H} 1$ is accepted, so the readiness of Village Government Worker has a positive and significant effect on IEC village funds. The results of this study are in accordance with the formulation of the hypothesis which states that the readiness of Village Government Worker has a positive effect on IEC village funds. This means that the higher or better the management of village funds is seen from the readiness of Village Government Worker, the communication process, providing information and education from Village Government Worker to village communities regarding the existence of the village fund program will increase. The results of this study support the results of previous studies by Marhaeni, et al. (2019) which state that the readiness of Village Government Worker is a prerequisite for the success of the village fund program

Table 2 Regression Test Results

\begin{tabular}{|c|c|c|c|c|c|c|}
\hline & \multirow{2}{*}{ Model } & \multicolumn{2}{|c|}{ Unstandardized Coefficients } & \multirow{2}{*}{$\begin{array}{c}\text { Standardized Coefficients } \\
\text { Beta }\end{array}$} & \multirow{2}{*}{$\mathrm{t}$} & \multirow{2}{*}{ Sig. } \\
\hline & & $\mathrm{B}$ & Std. Error & & & \\
\hline \multirow{3}{*}{1} & (Constant) & 1,694 & 1,214 & & 1,395 & 164 \\
\hline & $\begin{array}{l}\text { Village Government } \\
\text { Worker Readiness }\end{array}$ & , 198 & ,041 & ,252 & 4,860 & 000 \\
\hline & Village Fund & 658 &, 062 &, 554 & 10,671 & 000 \\
\hline
\end{tabular}

Primary Data, 2020

Based on Table 2, two tests can be obtained, namely the direct effect of Village Government Worker readiness on community empowerment and the direct effect of IEC village funds on community empowerment. The effect of Village Government Worker readiness on community empowerment is obtained $\alpha=0,05$, sig $t_{2}=0,000$ and beta value 0,252 . This means that the research hypothesis $\mathrm{H} 0$ is rejected and $\mathrm{H} 1$ is accepted, so the readiness of Village Government Worker has a positive and significant effect on community empowerment. The results of this study are in accordance with the formulation of the hypothesis which states that the readiness of Village Government Worker has a positive effect on community empowerment. This means that the higher or better the management of village funds is seen from the readiness of Village Government Worker the community empowerment will increase. The results of this study support the results of previous research by Hairi Firmansyah (2012) which shows that the role of the facilitator, in this case the village government, greatly determines the success of the empowerment program, namely the realization of community empowerment.

For the effect of IEC, village funds on community empowerment are obtained $\alpha=0,05$, sig $\mathrm{t}_{2}=0,000$ and beta value 0,554. This means that the research hypothesis $\mathrm{H} 0$ is rejected and $\mathrm{H} 1$ is accepted, so the IEC village funds have a positive and significant effect on community empowerment. The results of this study are in accordance with the formulation of the hypothesis which states that village fund IEC has a positive effect on community empowerment. This means that the higher or better the communication, information and education from the Village Government Worker to the village community, the community empowerment will increase. The results of this study support the results of previous research conducted by Nielsen and Christian (2003) that empowerment is related to the dissemination of information, providing knowledge, and appreciation of performance in encouraging increased skills, Syafruddin, et al (2019) indicate that communication support has a very real effect on the dynamics of empowerment. community as a result of the empowerment program, and Dahyar Daraba (2015) shows that communication has a positive effect on the success rate of the empowerment program

\section{B. $\quad$ Standard Error}

$\mathrm{e}_{1}$ shows the number of variants of the Village Fund IEC variables $\left(\mathrm{Y}_{1}\right)$ which is not explained by the Village Government Worker Readiness variable $\left(\mathrm{X}_{1}\right)$, to find out the $\mathrm{e}_{1}$ calculated using the formula:

$e_{i}=\sqrt{\left(1-R i^{2}\right)}$

$e_{1}=\sqrt{1-0,312}=0,829$

$\mathrm{Y}_{1}=0,559 \mathrm{X}_{1}+0,829$

$\mathrm{e}_{2}$ shows the number of variants of the Community Empowerment variable $\left(\mathrm{Y}_{2}\right)$ which is not explained by the Village Government Worker Readiness variable $\left(\mathrm{X}_{1}\right)$ and IEC Village funds $\left(\mathrm{Y}_{2}\right)$, to find out the $\mathrm{e}_{2}$ calculated using the formula:

$e_{i}=\sqrt{\left(1-R i^{2}\right)}$

$e_{2}=\sqrt{1-0,526}=0,688$

$\mathrm{Y}_{2}=0,252 \mathrm{X}_{1}+0,554 \mathrm{Y}_{1}+0,688$

\section{C. $\quad$ Validity}

There are indicators to check the validity of the model, namely the coefficient of determination of the total results:

$\mathrm{R}^{2} \mathrm{~m}=1-e_{1}^{2} \cdot e_{2}^{2}$ 


$$
\begin{aligned}
\mathrm{R}^{2} \mathrm{~m} & =1-(0,829)^{2}(0,688)^{2} \\
& =0,675
\end{aligned}
$$

Description:

$\mathrm{R}^{2} \mathrm{~m}=$ total determination coefficient

$\mathrm{e}_{1}, \mathrm{e}_{2}=$ default estimate error value

Based on the calculation, it is found that the diversity of data that can be explained by the model is 67.5 percent, which means that 67.5 percent of the variables of Village Government Worker readiness, IEC, village funds, and community empowerment can be explained by the model, while the remaining 32.5 percent is explained by other variables not included in the model.

\section{Sobel Test}

Testing the indirect effect is carried out through the following mediating variable hypothesis:

a) Hypothesis Formulation

$\mathrm{H}_{0}$ : Village fund IEC is not a mediating variable that indirectly influences the readiness of Village Government Worker on community empowerment.

H1: IEC village funds as a mediating variable have an indirect effect on the readiness of Village Government Worker on community empowerment.

b) Level of Significance

$$
\alpha=0,05
$$

z-table $=1,96$

c) Testing Criteria

a. If $\mathrm{p}$ value $\geq \alpha(0.05)$ or $\mathrm{z}$ count $\leq \mathrm{z}$ table $=1.96$, then $\mathrm{H} 0$ is accepted, which means $\mathrm{Y} 1$ does not mediate the effect of $\mathrm{X} 1$ on Y2.

b. If the $\mathrm{p}$ value $<\alpha(0.05)$ or $\mathrm{z}$ count $>\mathrm{z}$ table $=1.96$, then $\mathrm{H} 0$ is rejected, which means that $\mathrm{Y} 1$ mediates the effect of $\mathrm{X} 1$ on Y2.

d) Statistics Test

$$
\begin{aligned}
& \mathrm{Sab}=\sqrt{b^{2} S_{a}^{2}+a^{2} S_{b}^{2}} \\
& =\sqrt{(0,658)^{2}(0,034)^{2}+(0,368)^{2}(0,062)^{2}} \\
& =\sqrt{0,00102107624} \\
& \mathrm{Sab} \quad=0,03195428359 \rightarrow 0,03
\end{aligned}
$$

Testing the significance of the indirect effect requires the $\mathrm{z}$ value of the ab coefficient which is calculated by the following formula:

$$
\begin{aligned}
& \mathrm{z}=\frac{a b}{S_{a b}} \\
& \mathrm{z}=\frac{(0,368)(0,658)}{0,03}=8,07
\end{aligned}
$$

e) Conclusion

Based on the results, $\mathrm{z}$ value is $8.07>1.96$ which is the $\mathrm{z}$ value of the table, then $\mathrm{H} 0$ is rejected and $\mathrm{H} 1$ is accepted, which means that IEC village funds mediate the effect of Village Government Worker readiness on community empowerment in Klungkung Regency. The results of this study are in accordance with the formulation of the hypothesis which states that IEC village funds mediate the effect of Village Government Worker readiness on community empowerment. The results of this study are in line with research conducted by Syafruddin, et al (2019) which states that in order for empowerment programs to run effectively, it is necessary to restructure community institutions to realize freedom of expression, besides communication support makes it easier for people to obtain information needed in empowerment activities.

\section{CONCLUSION}

Theoretically, this research can provide scientific contributions and empirical evidence that the readiness of Village Government Worker affects the IEC village funds and community empowerment in Klungkung Regency. Village Government Worker readiness has a positive and significant effect on IEC village funds, Village Government Worker readiness has a positive and significant effect on community empowerment in Klungkung Regency, IEC village funds have a positive and significant effect on community empowerment in Klungkung Regency, and KIE village funds mediate the effect of Village Government Worker readiness on community empowerment in Klungkung Regency. 


\section{REFERENCES}

[1] Antlov, Hans, Anna Wetterberg \& Leni Dharmawan. 2016. Village Governance, Community Life, and the 2014 Village Law in Indonesia. Bulletin of Indonesian Economic Studies, 52:2, pp. 161-183.

[2] Banurea, Dina. 2018. Pemanfaatan Dana Desa dalam Pembangunan Desa (Studi Penelitian di Desa Perolihen Kecamatan Sitellu Tali Urang Jehe, Kabupaten Pakpak Bharat). Jurnal Ilmiah Mahasiswa FISIP Unsyah, 3(1).

[3] Daraba, Dahyar. 2015. Faktor-Faktor yang Mempengaruhi Keberhasilan Program Pemberdayaan Masyarakat Miskin di Kecamatan Polongbangkeng Utara Kabupaten Takalar Propinsi Sulawesi Selatan. Sosiohumaniora, 17(2), hal. 165-169.

[4] Edogbanya, Adejoh. 2013. Revenue Generation: Impact on Government Developmental Effort (A Study of Selected Local Council in Kogi East Senatorial District). Global Journal of Management and Business Research.

[5] Firmansyah, Hairi. 2012. Tingkat Keberdayaan Masyarakat dalam Program Pemberdayaan Masyarakat di Kota Banjarmasin dan Kabupaten Tanah Laut. Jurnal Agribisnis Perdesaan, 2(1), hal. 53-67.

[6] Gasper, Roz \& Annette Davies. 2016. Revisiting The Potential of Community Empowerment Within UK Neighbourhood Policing Meetings. Journal Policing and Society, 18:1, pp. 145-154.

[7] Gayatri, Made Yeni Latrini, Ni Luh Sari Widhiyani. 2017. Transparansi Dan Akuntabilitas Pengelolaan Keuangan Dana Desa Untuk Mendorong Kemandirian Masyarakat Pedesaan. Jurnal Ekonomi Kuantitatif Terapan, 10(2): hal. 175-182.

[8] Galster, G., Temkin, K., Walker, C., \& Sawyer, N. (2004). Measuring the impacts of community development initiatives: A new application of the adjusted interrupted time-series method. Evaluation review, 28:6, pp. 502-538.

[9] Gonçalves Barbosa, M., \& García del Dujo, Á. 2016. Education and StrugglesfFor Recognition: The Strategic Role of Empowerment. Revista Española De Pedagogía, pp. 283-296.

[10] Hermawan, Endang. 2019. Community Empowerment through Management of Village Funds Allocation in Indonesia. International Journal of Science and Society, 1:3, pp. 1-13.

[11] Husna, Saifatul. dan Abdullah, Syukriy. 2016. Kesiapan Aparatur Desa Dalam Pelaksanaan Pengelolaan Keuangan Desa Secara Akuntabilitas Sesuai Undang-Undang Nomor 6 Tahun 2014 Tentang Desa ( Studi pada Beberapa Desa di Kabupaten Pidie). Jurnal Ilmiah Mahasiswa Ekonomi Akuntansi (JIMEKA), 1(1), hal. 282-293.

[12] Kaiser, Angela A \& Lara Rusch. 2015. Trade-offs in Empowerment Though Social Action : Voices from Detroit. Community Development, 46:4, pp. 361-379.

[13] Marhaeni, AAIN. Sudibia, I Ketut \& Andika, Gede. 2019. Dana Desa untuk Kesejahteraan Rakyat "Membangun Desa, Membangun Indonesia”. Denpasar: CV. SASTRA UTAMA.

[14] Nielsen, J. F., \& Pedersen, C. P. 2003. The consequences and limits of empowerment in financial services. Scandinavian Journal of management, 19:1, pp. 63-83.

[15] Rahyuda, K. 2017. Metode Penelitian Bisnis. Denpasar: Udayana University Press.

[16] Sugiyono. 2014. Metode Penelitian Kuantitatif, Kualitatif, dan R\&D. Bandung: Alfabeta.

[17] Sugiyono. 2014. Metode Penelitian Kuantitatif, Kualitatif, dan R\&D. Bandung: Alfabeta.

[18] Sulumin, Husin Hasman. 2015. Pertanggungjawaban Penggunaan Alokasi Dana Desa pada Pemerintahan Desa di Kabupaten Donggala. E-Jurnal Katalogis. 3(1), hal. 43-53.

[19] Suyana Utama, Made. 2016. Aplikasi Analisis Kuantitaif. Denpasar : CV Sastra Utama.

[20] Syafruddin. dkk. 2019. Dinamika Keberdayaan Masyarakat di Sekitar Pertambangan di Kabupaten Bombana Sulawesi Tenggara. SOSIO KONSEPSIA, 8(3), hal. 255-266.

[21] Wenagama, I Wayan., \& Kartika, I Nengah. 2020. Dampak Dana Desa Terhadap Kemiskinan di Seluruh Kecamatan, Kabupaten Gianyar. Denpasar. 